ISSN: 1813-162X (Print) ; 2312-7589 (Online)
available online at: http://www.tj-es.com

Zedan AJ, Hummadi RA, Hussein SA. Effect of adding mixture of (concrete waste and asphalt waste) on the properties of gypseous soil. Tikrit Journal of Engineering Sciences 2019; 26(1):20-25.

\section{Adnan Jayed Zedan ${ }^{1, *}$ \\ Rizgar Ali Hummadi ${ }^{2}$ \\ Sarah Abdullah Hussein ${ }^{1}$}

\title{
Effect of Adding Mixture of (Concrete Waste and Asphalt Waste) on the Properties of Gypseous Soil
}

\author{
A B S T R A C T
}

The Gypseous soil which is used is taken from Tikrit city in Salah Aldeen governorate and specially from Tikrit University from a depth (1.5-2) m. It's type is sandy gravely with a small percentage of silt and clay while the percentage of gypsum is (34-36) \%. The tests on soil are standard proctor compaction, direct shear, collapsibility and California bearing ratio. The number of samples is (70). The effect of adding concrete waste (2, 4, 6 and $8 \%)$ and waste of Asphalt mixture $(2,4,6$ and 8$) \%$ on dry soil, as well as the effect of mixture of the optimum percentages of both additions on the properties of gypseous soil, is the aim of the study. Adding concrete waste at optimum percentage (6) \% causes an increase in maximum dry density at (16)\% and a decrease in optimum moisture content at (5) $\%$. Whereas adding concrete mixture waste in its optimum percentage (2) \% caused a decrease in maximum dry density values with an increase of optimum moisture content, and when adding a mixture of optimum percentage of waste, an increase happened in the M.D.D.(14)\% with a decrease in O.M.C. at (4) \%. Adding the optimum percentage (8) \% for both, the value of cohesion increases (100) \% when adding concrete waste with an increase in the angle of internal friction (14)\% and a decrease in collapsibility in a percentage of $(90) \%$, while adding waste of asphalt mixture shows an increase in cohesion value (112) \% with a decrease in the angle of internal friction (2) \% and a decrease in collapsibility in a percentage of (90) \%, when adding mixture of optimum percentages the value of cohesion increase (108) $\%$ with an increase in angle of internal friction (14)\% and a decrease in collapsibility in a percentage of (91) \%. Values of California Bearing Ratio in dry and soaked condition increases (49) \% when adding (8) \% of concrete wastes which is the optimum percentage, while adding waste of asphalt mixture causes a decrease in the value of C.B.R. and the optimum percentage is (2) \% , but adding optimum percentages mixture of them causes an increase in values of (52) \% in dry condition and (53)\% in soaked condition.

๑) 2019 TJES, College of Engineering, Tikrit University

Received $\quad 18$ January 2018

Accepted 14 November 2019

Available online 01 March 2019

2019 TJES, Collge of Engincering, Thiti University

DOI: http://dx.doi.org/10.25130/tjes.26.1.03

تأثير اضافة مزيج (مخلفات الخرسانة ومخلفات الاسفلت) على خصائص التربة الجبسية

التربة الجبسية المدروسة مأخوذة من مدينة تكريت في محافظة صلاح الدين وتحديداً من جامعة تكريت ومن عمق يتر اوح (1.5-2 (2.5) م، وإن نوعها هو رملية حصوية مع نسبة

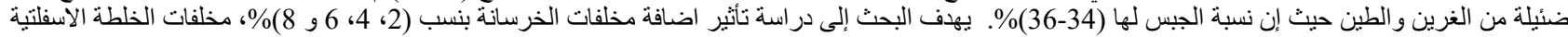

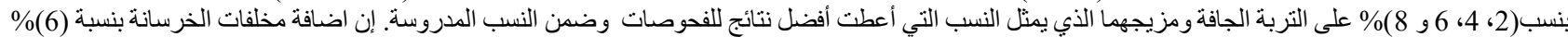

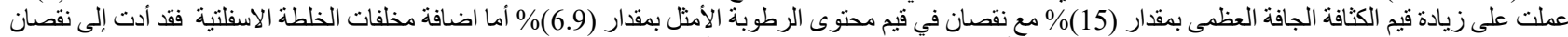
في قيم الكثافة الجافة العظمى مع زيادة في محتوى الرطوبة الأمثل. اضافة مخلفات الخرسانة أدت الى حصول زيادة في قيم التماسك بمقدار (100)\% مع حصول زيادة في 


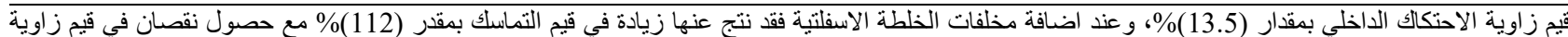

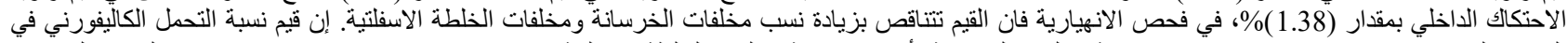

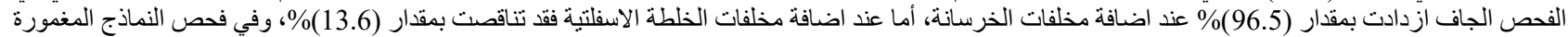
فقد ازدادت بمقدار (96.4)\% عند اضافة مخلفات الخرسانة، أما عند اضافة مخلفات الخلطة الاسفلتية فقد تناقصت بمقدار (40)\%

\section{INTRODUCTION}

Gypseous soil is found in many regions all over the world specially in the dry and semi dry regions, one of the regions is Iraq. It forms approximately $(28.6 \%)$ from soils of Iraq and covers more than (12.5) Million hectors from the total area [1].

This type of soil exists in Iraq's basin and correlated with areas of Tigris and Euphrates rivers. It is distinguished in having a high percentage of gypsum reached to (80)\% or more with thickness of five Meters and in some times It may cause a rocky solid gypsum horizon (petrogypsic) [2]. The waste of concrete and asphaltic mixture can be used in a good way to improve the properties of gypseous soil that suffering from problems, and that is so important from the economic side which decrease the cost of engineering projects. The gypseus soil is a stiff soil in dry condition but it loses its stiffness in the existence of water which is caused big crumbles because of the breaking of boundaries between the particles of soil due to the dissolve of gysum. The researchers improve properties of soil in a specified ways, [3] studying the improvement of gypseous soil by prewetting and the result shows a large decrease in percentage of (foundation settlement / foundation width) specially in the third recycle of soaking with water and the value of this reduction is (91)\%, [4] the effect of using stone columns on properties on gypseous soil is taken from Al-Door district in Salah Al-deen government with gypsum content (66)\%, the results shows a decrease in the value of collapsibility in a percentage of (56)\% and (53)\% when the value of applied pressure is (32) $\mathrm{kPa}$ and (4408) $\mathrm{kPa}$ respectively. Abdullah [5] studied the effect of washing on the properties of gypseous soil in Samaraa city in Iraq, the conclusion is a decrease in dry density because of removing some of gypsum content after washing while the values of specific gravity are increased and decreased in the porosity of soil. Ibrahim and Schanz [6] studied the improvement of gypseous soil using Silica oil, the results show that this material improves the compressibility and shear strength of soil.

\section{MATERIAL}

\subsection{Soil}

Gypseous soil is taken from Tikrit city in Salah AlDin government and specially from Tikrit University, at a depth (1.5-2 m) after removing the upper stratum of soil. Samples that taken are put in a plastic bags and transported to the laboratory. From Table 1 it can be concluded that the used soil is sandy gravely soil with small percentage of silt and clay. Table 2 shows the results of physical and chemical tests for normal soil.

\subsection{Concrete wastes and Asphalt mixture waste}

Concrete waste is taken from Tikrit city which is founded in many places. This waste is crushed using a special crusher machine and then sieved using sieve No.
(40) to using it as an additive to gypseous soil in the dry condition.

Asphalt mixture waste is taken from Tikrit city which is founded in many places. This waste is crushed using a special crusher machine after freezing it for several hours to avoid the changing of asphalt to dough and sieving it using sieve No. (40) to using it as an additive to the soil.

Table 1

Results of sieve analysis test.

\begin{tabular}{lll}
\hline $\begin{array}{l}\text { No. of sieve } \\
\text { (ASTM) }\end{array}$ & $\begin{array}{l}\text { Dia. of particle } \\
(\mathbf{m m})\end{array}$ & $(\%)$ of Passing \\
\hline $3 / 8$ in. & 9.51 & 100 \\
4 & 4.75 & 95.32 \\
10 & 2.00 & 84.54 \\
20 & 0.85 & 78.54 \\
30 & 0.60 & 60.01 \\
40 & 0.425 & 50.06 \\
60 & 0.25 & 24.66 \\
100 & 0.15 & 5.75 \\
200 & 0.075 & 2.96 \\
\hline
\end{tabular}

$\mathbf{C}_{\mathbf{u}}=3.243$ and $\mathbf{C}_{\mathbf{c}}=0.757$

Table 2

Results of physical and chemical tests.

\begin{tabular}{|c|c|c|c|}
\hline No & \multicolumn{2}{|l|}{ Test } & Results \\
\hline 1 & \multicolumn{2}{|c|}{ Water Content (\%) } & 8.5 \\
\hline 2 & \multicolumn{2}{|c|}{ Specific Gravity } & 2.59 \\
\hline \multirow{2}{*}{3} & \multirow{2}{*}{ Atterberg Limit } & L.L. & 26.5 \\
\hline & & P.L. & NP \\
\hline 4 & \multicolumn{2}{|c|}{ Gypsum Content (\%) } & 34.27 \\
\hline 5 & \multicolumn{2}{|l|}{ pH value } & 8.06 \\
\hline 6 & \multicolumn{2}{|c|}{ Organic Matters (\%) } & 0.51 \\
\hline 7 & \multicolumn{2}{|c|}{ Total Soluble Salts (\%) } & 45.5 \\
\hline 8 & \multicolumn{2}{|c|}{ Solphate Content (\%) } & 28 \\
\hline 9 & \multicolumn{2}{|c|}{ Type of Soil } & SP \\
\hline \multirow{3}{*}{10} & Standard & M.D.D. & \multirow{2}{*}{15.3} \\
\hline & Proctor & $\left(\mathrm{kN} / \mathrm{m}^{3}\right)$ & \\
\hline & Compaction & $\mathrm{OMC}(\%)$ & 14.14 \\
\hline \multirow{2}{*}{11} & \multirow{2}{*}{ Direct Shear } & $\mathrm{c}(\mathrm{kPa})$ & 37.5 \\
\hline & & $\square^{\mathrm{o}}$ & 39.64 \\
\hline 12 & \multicolumn{2}{|c|}{ Potential Collapse $(\%)$} & 12.061 \\
\hline \multirow{2}{*}{13} & \multirow{2}{*}{ CBR } & dition & 23.4 \\
\hline & & condition & 2.8 \\
\hline
\end{tabular}

\subsection{Method of Mixing}

The soil is sieved by using specific sieve for each test and heated in the oven, the degree is $\left(40^{\circ}-50^{\circ}\right)$ to 
prevent drying the gypsum [7] and then it be taken a specific weight of soil depending on the type of the test, adding weight percentage of the weight of dry soil and mixed by hand or plastic bag with continuous movement until It becomes a homogenous mixture.

\section{RESULTS AND DISCUSSION 3.1. Standard Procter Test}

Figs. 1 and 2 show the relationship between the effect of percentages adding on maximum dry density and optimum moisture content, Table 3 shows the result of this test.

It can be concluded that optimum percentage of concrete wastes is $(6 \%)$ which has the maximum value of dry density and with value of optimum moisture content. The optimum percentage of asphalt mixture wastes is (2\%) which has the maximum value of dry density and with value of optimum moisture content, the standard of this test is (ASTM D698-12)

The reason behind the increase of max. dry density until the percentage (6) \% belong to adding materials that passed from sieve No. (40) which improves the gradation of used soil so It leads to the increase [8]. While the reason of decrease in dry density at (8\%) is that the adding is filling materials cohesionless caused a decreased in cohesive soil materials [9].

The asphalt waste mixture causes a decrease in the dry density and an increase in moisture content, the main reason for decreasing is the density of added mixture is less than density of soil while the reason of increasing of moisture content is the viscosity of added material which is more than water's viscosity so that leads to an increase [10].

Table 3

Results of proctor compaction test.

\begin{tabular}{lllll}
\hline No. & $\begin{array}{l}\text { Type of } \\
\text { Addition }\end{array}$ & $\begin{array}{l}\text { Addition } \\
(\boldsymbol{\%})\end{array}$ & $\begin{array}{l}\text { M.D.D. } \\
\left(\mathbf{k N} / \mathbf{m}^{\mathbf{3}}\right)\end{array}$ & $\begin{array}{l}\text { OMC } \\
(\boldsymbol{\%})\end{array}$ \\
\hline 1 & No additive & 0 & 15.38 & 14.14 \\
2 & & 2 & 15.88 & 14.00 \\
3 & Concrete & 4 & 16.55 & 13.83 \\
4 & Wastes & 6 & 17.70 & 13.50 \\
5 & & 8 & 17.30 & 13.22 \\
6 & & 2 & 15.25 & 14.28 \\
7 & Asphaltic & 4 & 15.04 & 14.58 \\
8 & mixture & 6 & 14.80 & 14.76 \\
9 & Wastes & 8 & 17.76 & 13.64 \\
& Opt. (\%) of & & & \\
& (Concrete+ & & & \\
10 & Asphaltic) & $6+2$ & 17.55 & 13.64 \\
& wastes & & &
\end{tabular}

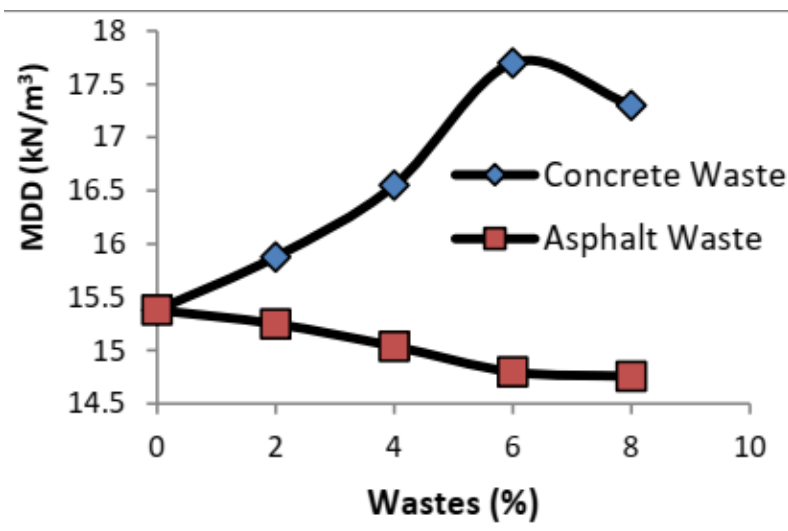

Fig. 1. Relationship between percentages of wastes and maximum dry density

\subsection{Direct Shear Test}

Figs. 3 and 4 show the relationship between normal stress and shear stress for four cases (natural samples, curing samples with concrete waste, curing samples by adding asphalt mixture and with the optimum percentage of them), The results of direct shear test are showed in Table 4.

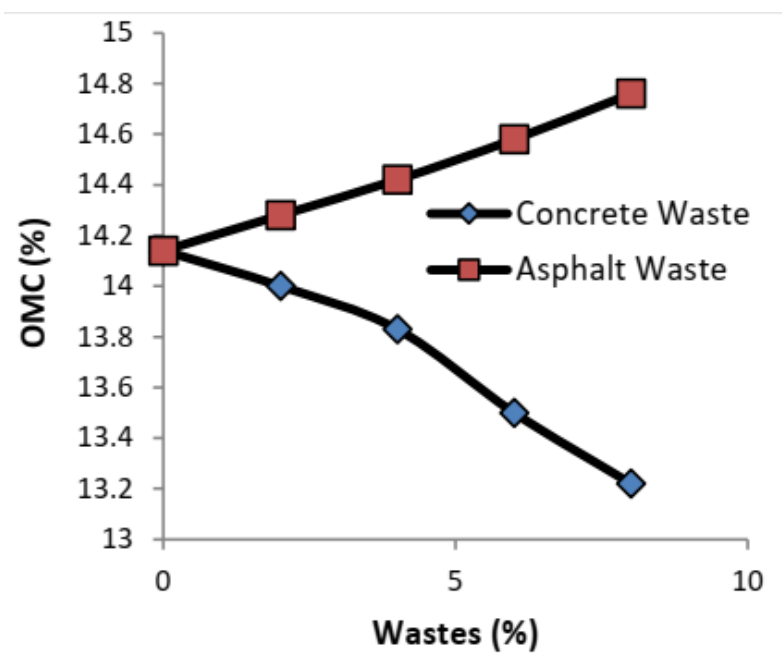

Fig. 2. Relationship between percentages of wastes and optimum moisture content

Using equation of Terzaghi and Meyerhof by substituting the values of direct shear test it can be concluded that the optimum percentages of adding were (8)\% which the maximum value of bearing capacity for soil's samples, and in the fourth case the optimum percentages are used to have the maximum value of bearing capacity, The standard of this test was (ASTM D3080-11).

Adding concrete mixture to the soil caused an increase in strength of soil, the reason behind that is, these materials free the calcium which created (Attringite), while the angle of friction is increased with the increase of adding mixture, and the reason was that material caused an increase in the friction between soil particles [11,12].

Adding concrete waste mixture to the soil made an increase in the cohesion between soil particles and reduce 
the permeability of water through it and the reason behind that is only physical factors without any chemicals interactions happened, [10].

Many researches find that strength of soils increases with the increase of asphaltic materials but the percentage of adding should not exceed the optimum percentage otherwise that will lead to decrease in strength of soil [13]. While the angle of friction decreased with the increase of asphaltic material and that happened because these materials facilitate the slipping of particles.

\section{Table 4}

Results of direct shear test.

\begin{tabular}{lllll}
\hline No. & $\begin{array}{c}\text { Type of } \\
\text { Addition }\end{array}$ & $\begin{array}{c}\text { Addition } \\
(\boldsymbol{\%})\end{array}$ & $\begin{array}{c}\text { c } \\
(\mathbf{k P a})\end{array}$ & $\square^{\mathbf{0}}$ \\
\hline 1 & No additive & 0 & 37.5 & 39.64 \\
2 & & 2 & 50 & 72.93 \\
3 & & 4 & 61.66 & 43.00 \\
4 & Concrete Wastes & 6 & 74.50 & 44.63 \\
5 & & 8 & 75.00 & 45.00 \\
6 & & 2 & 55.00 & 39.92 \\
7 & Asphaltic & 4 & 65.00 & 39.50 \\
8 & mixture Wastes & 6 & 70.50 & 39.24 \\
9 & & 8 & 79.50 & 39.1 \\
& Opt. (\%) of & & & \\
10 & (Concrete+ & & & \\
& Asphalti) wastes & $8+8$ & 78.00 & 45.00
\end{tabular}

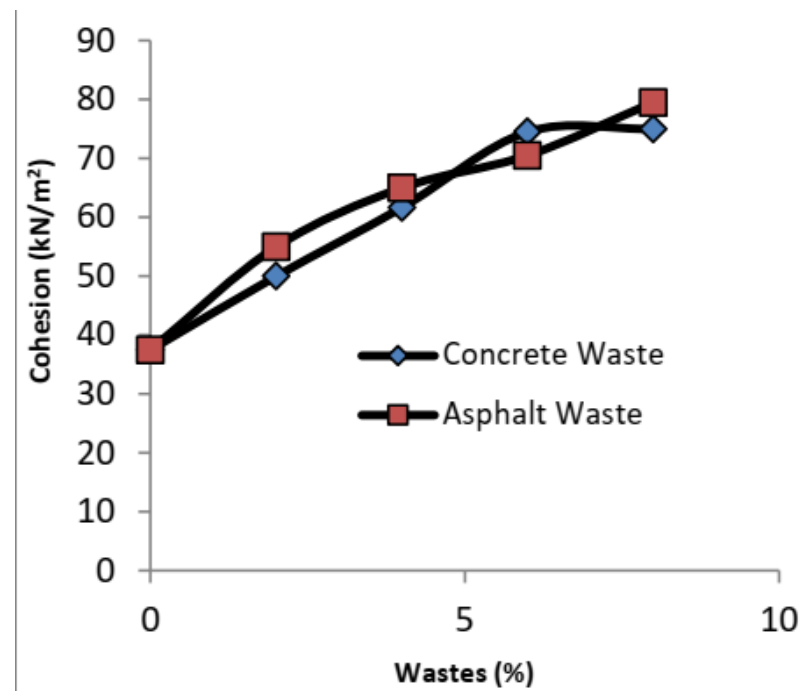

Fig. 3. Relationship between percentages of wastes and cohesion.

\subsection{Collapse Potential Test}

Fig. 5 shows the relation between percentages of waste with the values of collapse potential. The optimum percentages of adding (concrete waste and asphalt mixture waste) was ( $8 \%$ ) because it has the minimum value of potential collapse. In the fourth stage from work steps the optimum percentages of each adding are used to reach the best value of potential collapse, the values of potential collapse and initial void ratio for the samples of gypsum soils are shown in Table 5. From the show results It can be concluded that the potential collapse decrease with the increase of adding mixtures, the reason behind this decrease belongs to many causes such as this adding acts as a cover for the gypseous particles subsequently reduce or prevent the effect of water on the particles, and the concrete waste mixture act as a bonding materials between soil particles [14].

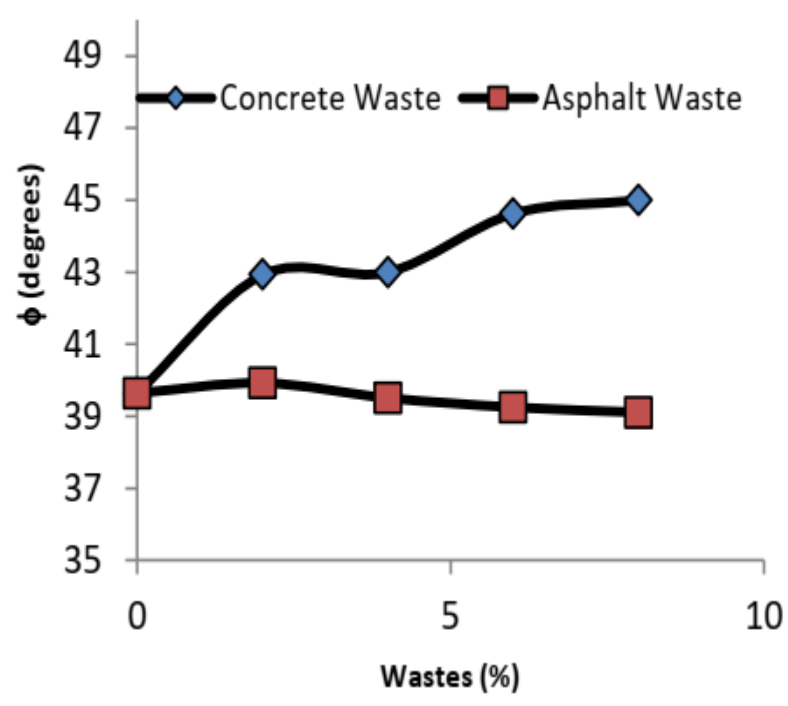

Fig. 4. Relationship between percentages of wastes and angle of internal friction.

\subsection{California Bearing Ratio Test}

Figs. 6-9 show the relation between No. of blows and C.B.R. for the waste for both conditions. The results of this test for both conditions are shown in Table 6 for natural soil and curing soil with concrete and asphaltic mixtures wastes using optimum moisture content.

The results for both condition show an increase in C.B.R. values when the concrete waste increase and the optimum percentage is (8)\%, while the adding of asphaltic mixture causes a decreased in the values and the optimum percentage is (2)\%, The standard of this test is (ASTM D1883-99).

The reason of the increase of the values for C.B.R. in both conditions (dry and soaked) is the concrete waste mixture caused an increase in the density of the samples where these materials a filling materials cause an increased in the friction between soil particles which lead to increase soil strength at all [15]. While the reason of decrease in values of C.B.R in both conditions when the asphalt waste mixture added, the reason is as a result for the decrease in density as mentioned in above. 
Table 5

Results of Collapse test.

\begin{tabular}{ccccc}
\hline No. & $\begin{array}{c}\text { Type of } \\
\text { Addition }\end{array}$ & $\begin{array}{c}\text { Addition } \\
(\%)\end{array}$ & $\begin{array}{c}\text { Initial } \\
\text { void } \\
\text { ratio } \\
\left(\mathbf{e}_{\mathbf{o}}\right)\end{array}$ & $\begin{array}{c}\text { Collapse } \\
\text { potential } \\
\left(\mathbf{C}_{\mathbf{p}}\right)\end{array}$ \\
\hline 1 & No additive & 0 & 0.7724 & 7.7804 \\
2 & Concrete & 2 & 0.7633 & 1.0151 \\
3 & Wastes & 4 & 0.6401 & 1.0060 \\
4 & & 6 & 0.6411 & 0.9444 \\
5 & & 8 & 0.5302 & 0.7384 \\
6 & Asphaltic & 2 & 0.7505 & 1.0854 \\
7 & mixture & 4 & 0.6355 & 0.9293 \\
8 & Wastes & 6 & 0.6543 & 0.8704 \\
9 & & 8 & 0.5278 & 0.7068 \\
10 & Opt. (\%) of & $8+8$ & 0.5322 & 0.6433 \\
& (Concrete+ & & & \\
\multicolumn{7}{c}{ Asphaltic) } & & & \\
\hline
\end{tabular}

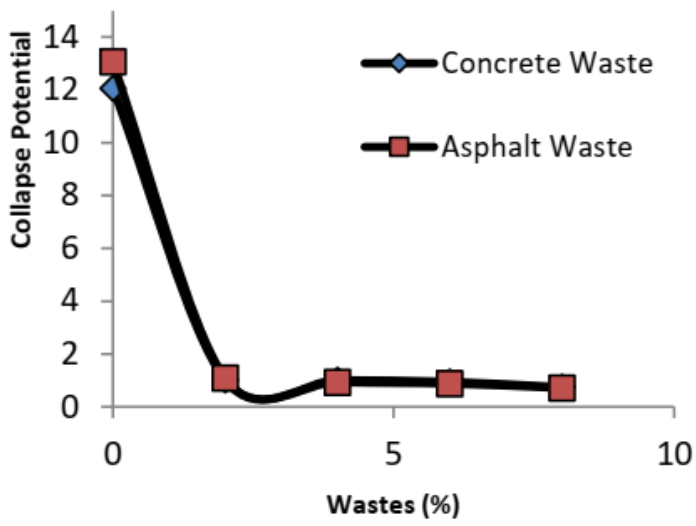

Fig. 5. Relationship between percentages of wastes and collapse potential.

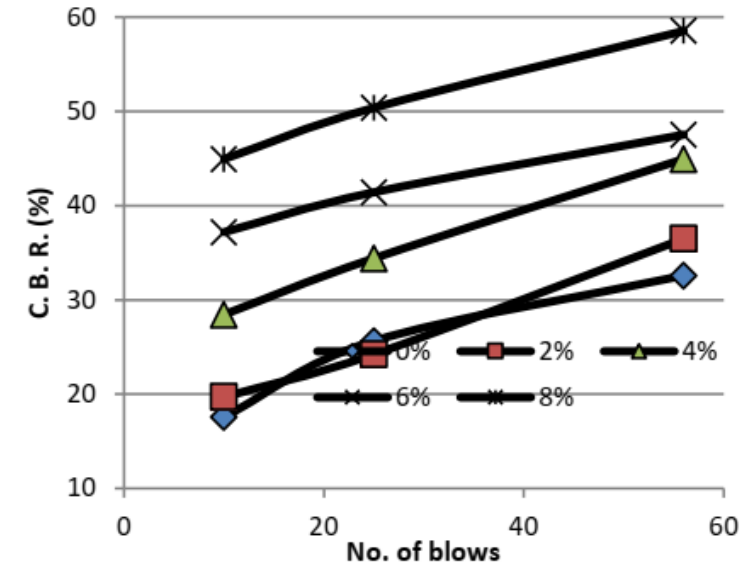

Fig. 6. Relationship between No. of blows with C.B.R. for concrete wastes (dry condition)
Table 6

Results of California bearing ratio test.

\begin{tabular}{|c|c|c|c|c|}
\hline \multirow[t]{2}{*}{ No. } & \multirow{2}{*}{$\begin{array}{l}\text { Type of } \\
\text { Addition }\end{array}$} & \multirow{2}{*}{$\begin{array}{l}\text { Addition } \\
(\%)\end{array}$} & \multicolumn{2}{|l|}{ CBR } \\
\hline & & & $\begin{array}{l}\text { Dry } \\
\text { Cond. }\end{array}$ & $\begin{array}{l}\text { Soaked } \\
\text { Cond. }\end{array}$ \\
\hline 1 & No additive & 0 & 23.4 & 2.8 \\
\hline 2 & Concrete & 2 & 21.6 & 2.9 \\
\hline 3 & Wastes & 4 & 30.5 & 3.7 \\
\hline 4 & & 6 & 38.5 & 4.5 \\
\hline 5 & & 8 & 46 & 5.5 \\
\hline 6 & Asphaltic & 2 & 22.8 & 2.6 \\
\hline 7 & mixture & 4 & 21.4 & 2.6 \\
\hline 8 & Wastes & 6 & 21.3 & 2.2 \\
\hline 9 & & 8 & 20.6 & 2.0 \\
\hline 10 & $\begin{array}{l}\text { Opt. (\%) of } \\
\text { (Concrete+ } \\
\text { Asphaltic) } \\
\text { wastes }\end{array}$ & $8+2$ & 49 & 6.0 \\
\hline
\end{tabular}

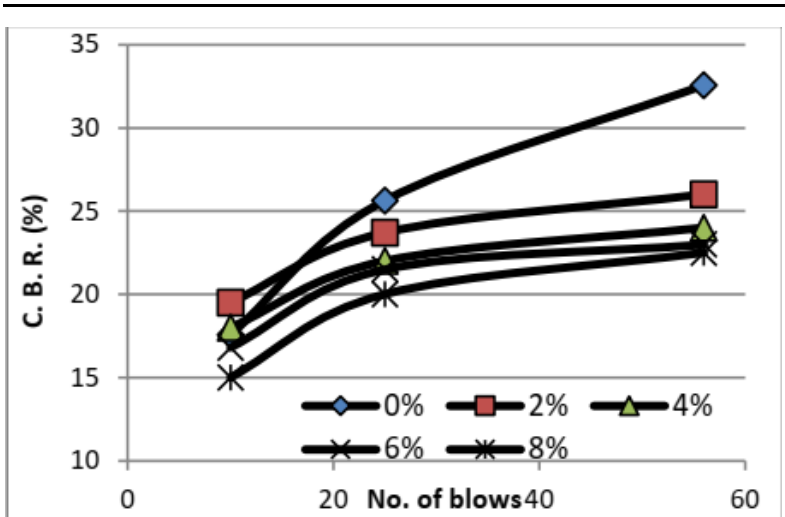

Fig. 7. Relationship between No. of blows with C.B.R. for Asphalt wastes (dry condition).

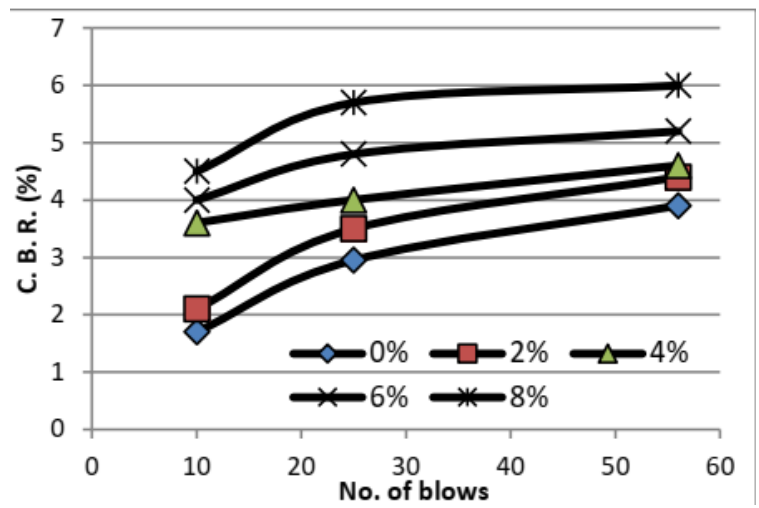

Fig. 8. Relationship between No. of blows with C.B.R. for concrete wastes (soaked condition).

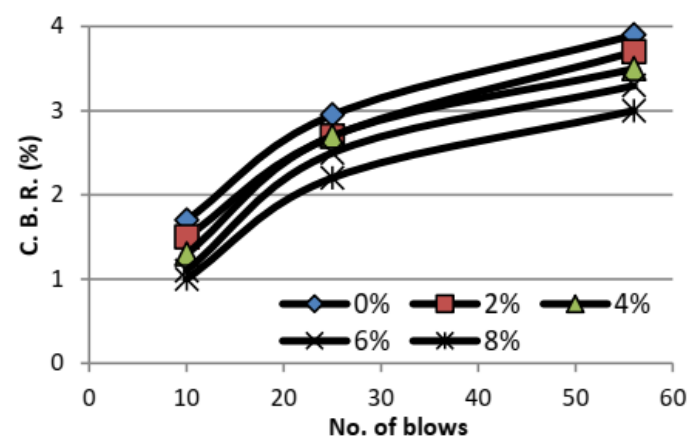

Fig. 9. Relationship between No. of blows with C.B.R. for Asphalt wastes (soaked condition) 


\section{CONCLUSION}

1. The values of M.D.D. in standard Procter compaction test increase with the increase of concrete wastes, in which $6 \%$ represent the optimum value, while the values of M.D.D. decrease with the increase of asphalt mixture wastes and the optimum value is $2 \%$, while adding of optimum percentages of wastes, the value of maximum dry density increase in a magnitude of $14 \%$. The values of optimum moisture content decrease in a magnitude of $5 \%$ with the increase of concert wastes and the optimum value is $8 \%$, the adding of asphalt mixture caused an increase in values of optimum moisture content in $2 \%$ which represents the optimum value. In the fourth stage of work steps the values of optimum moisture content are decreased in a magnitude of $4 \%$.

2. The values of cohesion and angle of internal friction increase with the increase of concrete wastes, in which the cohesion increases in a magnitude of $100 \%$ and angle of internal friction in a magnitude of $14 \%$, the value $8 \%$ represent the optimum percentages. When asphalt mixture wastes are added, the cohesion increase in a magnitude of $112 \%$ with a decrease in the angle of internal friction in a magnitude of $2 \%$ and the optimum percentage is $108 \%$ with an increase in the angle of internal friction in a magnitude of $14 \%$.

3. The values of potential collapse in collapse test are decreased in a magnitude of $90 \%$ when the waste is added separately and the optimum percentage is $8 \%$. While the value of potential collapse decreases in a magnitude of $91 \%$ when the waste is added composedly.

4. The value of C.B.R. in dry and soaked conditions increases in a magnitude of $49 \%$ when the percentage $8 \%$ of concrete waste is added, while the adding of asphalt mixture caused a decrease in vale of C.B.R. and the optimum percentage is $2 \%$. When both of waste are added the values increase in a magnitude of $52 \%$ in dry condition and $53 \%$ in soaked condition.

\section{REFERENCES}

[1] Jafarzadeh AA, Zinck JA. Worldwide distribution and sustainable management of soil with gypsum. 2000. ISD Ana sayfasi.

[2] Al-Barzanji AF. Gypsiferous soils of Iraq. Ph.D. Thesis, State University of Ghent, Belgium: 1973.
[3] Abid Awn SH. Improvement of gypseous soil by pre-wetting. Diyala Journal of Engineering Sciences 2011; 4(1): 71-82.

[4] Mirza AN. Field models on gypseous soil reinforced with stone columns stabilized with asphalt and cement. M.Sc. Thesis, Building and Construction Department, University of Technology, Baghdad: 2003.

[5] Abdullah KA. The effect of washing on properties of gypseous soil in Samarra-Iraq. PhD Thesis, Geologic Engineering Dept., Baghdad University: 2005.

[6] Ibrahim AN, Schanz T. Gypseous soil improvement by silicone oil. Al-Nahrain Journal for Engineering Sciences 2017; 20(1): 49-58.

[7] Al-Mufty AA, Nashat IH. Gypsum content determination in soils and rocks. 3rd International Jordanian Conference on Mining 2000: 500-506.

[8] Al-Ashoo MO. Principles of soil mechanism. Dar Ibn Al-Atheer for printing and publishing, Mosul University, Iraq: 1991. (in arabic).

[9] Al-Khashab MN, Thafer A-HM. Treatment of Expansive Clayey Soil with Crushed Limestone. Civil Eng Dept Collage of Eng Mosul University Engineering \& Technology Journal 2008; 26:376386.

[10] Ingles OG, Metcalf JB. Soil stabilization principles and practice. Australia; 1972.

[11] Chen D-H, Harris P, Scullion T, Bilyeu J. Forensic investigation of a sulfate-heaved project in Texas. Journal of Performance of Constructed Facilities 2005; 19(4):324-330.

[12] Si Z. Forensic investigation of pavement premature failure due to soil sulfate-induced heave. Journal of Geotechnical and Geoenvironmental Engineering 2008;134(8):1201-1204.

[13] Edwin LH. The stability of stabilized soil for building construction. University of Illinois Engineering Experiment Station, Bulletin Series No. 33, 2007: pp.7.

[14] Fattah MY, Al-Ani MM, Al-Lamy MT. Studying collapse potential of gypseous soil treated by grouting. Soils and Foundations 2014;54(3):396404.

[15] Razouki SS, Kuttab DK. predictive equation for soaked CBR of a clayey gypsiferous soil. Engineering and Technology 2002; 21(8). 